\title{
PANI PROFESOR ANNA ZORSKA - BIOGRAM NAUKOWY
}

Pani Profesor Anna Zorska urodziła się 14 lipca 1947 r. w Dęblinie. Ma dwoje dzieci - córkę Paulinę i syna Witolda. Całe swoje dorosłe życie związała ze Szkołą Główną Handlową w Warszawie (poprzednia nazwa - Szkoła Główna Planowania i Statystyki), gdzie w drugiej połowie lat 60. XXw. podjęła studia, a na początku kolejnej dekady pracę naukowo-badawczą (1972-2017).

Tytuł zawodowy magistra ekonomii Anna Zorska uzyskała w 1970 r. po ukończeniu studiów wyższych ekonomicznych na Wydziale Handlu Zagranicznego Szkoły Głównej Planowania i Statystyki w Warszawie. Już w tym okresie zaczęly kształtować się Jej zainteresowania naukowe, których inspiracją były seminaria magisterskie nt. analizy rynków zagranicznych. Przemiany i tendencje ekonomiczno-technologiczne zachodzące zarówno na rynku międzynarodowym, jak i w gospodarce światowej stały się - w późniejszym okresie pracy dydaktycznej i naukowej - głównym obszarem zainteresowań oraz badań.

Zdobyta wiedza, kompetencje i umiejętności badawcze w zakresie analizy rynków zagranicznych znalazły także praktyczne zastosowanie w trakcie podjętej w $1970 \mathrm{r}$. pierwszej pracy zawodowej $w$ resorcie przemysłu maszynowego, $w$ sekcji badawczej.

W 1972 r. mgr Anna Zorska została zatrudniona w SGPiS w Instytucie Gospodarki Krajów Rozwijających się (IGKR) na stanowisku asystenta, gdzie mogła kształtować i rozwijać swoje zainteresowania oraz zamiłowanie do pracy naukowej, która sensu largo obejmowała procesy toczące się w gospodarce światowej. Studia teoretyczne i badania empiryczne nad gospodarką krajów rozwijających się pozwoliły Jej skoncentrować się na zagadnieniach industrializacji, ujętych w szerokim kontekście ogólnych tendencji zmian w światowym przemyśle. Po kryzysie naftowym w 1974 r. pojawily się tė̇ nowe zainteresowania, które objęły m.in. zagadnienia takie jak: napływ dochodów naftowych i ich wykorzystanie przez niektóre kraje (Arabię Saudyjską, Iran), narastająca polaryzacja Trzeciego Świata, zmiany w polityce gospodarczej i technologicznej niektórych krajów rozwijających się. Tej problematyce stricte poświęcone zostały pierwsze publikacje dorobku naukowo-badawczego Anny Zorskiej.

Podsumowaniem prowadzonych badań naukowych stała się przygotowana dysertacja doktorska pt. "Zmiany na światowym rynku bawełnianym oraz ich wpływ na polski przemysł i handel zagraniczny", na podstawie której - po złożeniu 
egzaminów doktorskich - uchwałą Rady Naukowej Wydziału Handlu Zagranicznego SGPiS z dnia 17 czerwca 1981 r. Anna Zorska uzyskała stopień naukowy doktora nauk ekonomicznych.

Istotnym wkładem w rozwój dziedziny nauk ekonomicznych były wyniki pionierskich prac badawczych, prowadzonych w okresie 1986-1997, a opublikowanych pod koniec lat 90. Opracowania i publikacje dotyczyły postępu naukowo-technicznego oraz wykorzystania nowych technologii w strategicznych dziedzinach przemysłu - z jednej strony, $z$ drugiej zaś stały się próbą formułowania wniosków i rekomendacji dla polityki technologicznej państwa. Silny wzrost cen ropy naftowej w tamtym okresie skierował uwagę Pani Doktor na struktury przemysłowe (w produkcji, wymianie, inwestycjach) i ich ewolucję, polegającą na przechodzeniu dziedzin energo- i materiałochłonnych ku nowym dziedzinom opartym na wykorzystaniu zaawansowanych technologii, zwłaszcza mikroelektronicznych.

Kolejnym obszarem zainteresowań stała się działalność korporacji transnarodowych (KTN) jako podmiotów w dużej mierze wpływających na tworzenie nowych technologii oraz kreowanie zmian w zakresie produkcji i wymiany przemysłowej. W szczególności zainteresowania Anny Zorskiej koncentrowały się na zagranicznych inwestycjach bezpośrednich, traktowanych jako specyficzna dla korporacji transnarodowych forma międzynarodowej ekspansji przedsiębiorstw. Niewątpliwie ich motywy, warunki, zmiany intensywności przepływów, ewolucja tendencji i struktur stanowiły temat ważny i interesujący, dodać warto również - trudny i mało rozpoznany.

Autorska koncepcja globalizacji jako złożonego procesu o wielkim znaczeniu dla gospodarki światowej, poszczególnych krajów i różnego rodzaju podmiotów (wraz z powszechnie akceptowalną, po dzień dzisiejszy, definicją globalizacji) została opublikowana przez Wydawnictwo Naukowe PWN $(1998,2000,2001)$ w książce Ku globalizacji? Przemiany w korporacjach transnarodowych $i$ w gospodarce światowej. Przygotowana monografia posiadała liczne walory merytoryczne: po pierwsze, była pierwszą publikacją nt. globalizacji i globalnej ekspansji korporacji transnarodowych, po drugie, znacząco przyczyniła się do spopularyzowania w Polsce teorii międzynarodowego biznesu i zarządzania oraz ich wykorzystania w różnego rodzaju interdyscyplinarnych badaniach i po trzecie stała się najczęściej cytowaną pozycją literaturową w krajowych badaniach i publikacjach dotyczących międzynarodowych stosunków gospodarczych. Wyrazem uznania dla Autorki tej książki, napisanej - jak podkreślali recenzenci - w sposób bardzo interesujący i przystępny, były: Nagroda indywidualna I stopnia Ministra Edukacji Narodowej, wyróżnienie Polsko-Amerykańskiego Funduszu Przedsiębiorczości oraz Nagroda I stopnia Rektora SGH. Monografia wraz z dorobkiem dydaktycznym stała się także podstawą uzyskania stopnia doktora habilitowanego nauk ekonomicznych (uchwałą Rady Kolegium 
Ekonomiczno-Społecznego Szkoły Głównej Handlowej w Warszawie z dnia 21 października 1999 r.).

Pogłębianie badań nad globalizacją jako kompleksowym i fundamentalnym procesem skierowało zainteresowania i badania Pani Profesor na inne, ogromnie ważne przemiany we współczesnej gospodarce światowej, w tym na regionalizację (w szczególności dotyczy ugrupowania integracyjnego - Unii Europejskiej). Zagadnieniom regionalizacji oraz integracji regionalnej UE, głównie z punktu widzenia działalności korporacji transnarodowych, poświęcone zostało wiele pozycji dorobku naukowego Anny Zorskiej.

Do rozwoju naukowego i zawodowego przyczyniły się odbyte zagraniczne staże naukowe: University of Minnesota - USA (1995r.), University of Sussex - Wielka Brytania (2002 r.) i Sciences Po - Francja (2002 r.) oraz udział w konferencjach krajowych i zagranicznych. Ważnym wydarzeniem był także udział w ogólnoświatowej XII Konferencji Generalnej EADI pt. „Global Governance for Sustainable Development. The Need for Policy Coherence and New Partnerships", Genewa 2008, z prezentacją referatu „Innovation Activity of Transnational Corporations. Implications for Poland”.

Cennej wiedzy i doświadczenia dostarczyła również praca w Katedrze Zarządzania kierowanej przez Profesora Andrzeja K. Kó́mińskiego - Akademia Leona Koźmińskiego (2000-2005) oraz seminaria w Katedrze Biznesu Międzynarodowego kierowanej przez prof. zw. dr. hab. Marcina K. Nowakowskiego - SGH.

Początek XXIw. w ekonomii międzynarodowej to dość intensywne przemiany w procesie globalizacji, które $\mathrm{w}$ dużej mierze dokonały się pod wpływem przyspieszenia postępu naukowo-technicznego, zwłaszcza powstania i implementacji w praktyce nowej generacji technologii informacyjnych i komunikacyjnych. Wykorzystanie tych technologii uruchomiło nową falę innowacyjnych przemian w produktach i procesach wytwórczych, a przede wszystkim w infrastrukturze i komunikowaniu się przedsiębiorstw, w kwalifikacjach kadr oraz metodach zarządzania, organizacji i marketingu. Wszystko to stało się nowym nurtem zainteresowań prof. nadzw. dr hab. Anny Zorskiej, a nowe uwarunkowania funkcjonowania gospodarek i ich rozwój (w kierunku gospodarek opartych na wiedzy i informacjach) stały się nową ścieżką rozwoju naukowego.

Efektem badań wykorzystania nowych technologii i innowacji w przedsiębiorstwach - zwłaszcza w ich zagranicznej ekspansji - stała się książka nt. opartych na informacyjnych i komunikacyjnych technologiach, informacjach i wiedzy przemian dokonujących się wewnątrz korporacji transnarodowych, w różnych formach ich ekspansji międzynarodowej oraz w globalnych otoczeniu gospodarczym. Monografia Korporacje transnarodowe. Przemiany, oddzialywania, wyzwania (PWE, Warszawa 2007) stanowi pierwsze w polskiej literaturze tematu tak kompleksowe i zintegrowane ujęcie problematyki korporacji, które eksponuje podejście do tych podmiotów 
przez pryzmat biznesu międzynarodowego, jednocześnie zawierając wątki międzynarodowego zarządzania oraz międzynarodowych stosunków gospodarczych.

Doceniając ówczesną pracę dydaktyczną (wykłady, seminaria) oraz opublikowany dorobek naukowy, Prezydent Rzeczypospolitej Polskiej Lech Kaczyński postanowieniem z dnia 13 stycznia 2009 r. nadał Annie Zorskiej tytuł naukowy profesora nauk ekonomicznych.

W latach 2001-2013 prof. zw. dr hab. Anna Zorska pełniła funkcję Kierownika Zakładu Globalizacji i Regionalizacji ISM KES SGH, natomiast w okresie 2013-2017 - Kierownika Zakładu Międzynarodowej Polityki Ekonomicznej ISM KES SGH.

Pani Profesor Anna Zorska wypromowała czterech doktorów: dr. Radosława Malika (17 marca 2015 r.) - „Wykorzystanie lokalizacji zagranicznych w procesie przenoszenia usług biznesowych przez korporacje transnarodowe"; dr. Marcina Slepko (24 listopada 2011 r.) - „Umiędzynarodowienie klastrów gospodarczych pod wpływem ekspansji korporacji transnarodowych"; dr. Tomasza Walczuka (22 czerwca 2006 r.) - „Gospodarka rentierska w dobie globalizacji. Ekonomiczne problemy i wyzwania A rabii Saudyjskiej” i dr Agnieszkę Jankowską (19 maja 2005 r.) - „Dochodzenie kraju do aktywnego uczestnictwa w procesie globalizacji. Elementy strategii dla Polski”.

Wśród licznych nagród i wyróżnień, którymi uhonorowana została Pani Profesor, najważniejszą chyba jest ta otrzymana w 2017 r. - Nagroda I stopnia Rektora SGH za całokształt pracy naukowej, dydaktycznej i organizacyjnej.

Dorobek naukowy Anny Zorskiej obejmuje ponad 150 opublikowanych pozycji (równicż w języku angielskim), w tym dwie autorskie książki: Ku globalizacji? Przemiany w korporacjach transnarodowych $i$ w gospodarce światowej (Wydawnictwo Naukowe PWN, Warszawa 1998, 2000, 2002) oraz Korporacje transnarodowe. Przemiany, oddzialywania, wyzwania (PWE, Warszawa 2007).

Pani Profesor zw. dr hab. Anna Zorska to wielce zasłuzony pracownik naukowy i dydaktyczny naszego Instytutu Studiów Międzynarodowych Kolegium Ekonomiczno-Społecznego SGH. Współpracownicy Pani Profesor podkreślają Jej ciepło, wrażliwość i zyczliwość. Jak przystało na Mistrzynię, jest wymagająca, ale jednocześnie pomocna i wspierająca, zawsze służąca swoją wiedzą, doświadczeniem i doradztwem.

Jesteśmy dumni, że mogliśmy wspólpracować z taką Szefową!

Składamy Pani Profesor najserdeczniejsze życzenia wielu lat w zdrowiu, spełnienia marzeń i realizacji zyciowych planów, a takze sił do aktywności na tych polach oraz wszelkiej pomyślności w życiu osobistym.

w imieniu pracowników Instytutu Studiów Międzynarodowych i Kolegium Ekonomiczno-Społecznego Roman Wosiek 